\title{
EFFICACY OF TWO SPECIES OF COCCINELLID PREDATORS AGAINST FOUR DIFFERENT APHID PEST SPECIES AT KHUMALTAR, NEPAL
}

\author{
B. Maharjan ${ }^{1}$, R.B. Thapa ${ }^{2}$ and A.S.R. Bajracharya ${ }^{1}$ \\ ${ }^{1}$ Nepal Agricultural Research Council, Khumaltar, Lalitpur \\ ${ }^{2}$ Institute of Agriculture and Animal Science, Tribhuvan University, Nepal \\ *bmaharjan447@gmail.com
}

\begin{abstract}
An experiment was conducted in completely randomized design (CRD) to study the efficacy and biology of two coccinellid species with four aphid species at the mass-rearing laboratory of Entomology Division, Nepal Agricultural Research Council (NARC), Khumaltar from February to May 2016. Two coccinellid species, i.e. Coccinella septumpunctata Linn. and Adonia variegate (Goeze) were given four aphid species viz; Myzus persicae (Sulzer), Lipaphis erysimi (Kaltenbach), Aphis craccivora (Koch) and Brevicorynae brassicae Linn. separately to compare the efficacy of two beetle species as effective bio-control agent. Predatory activity of C. septumpunctata was the highest on L. erysimi(feeding 183 aphids) and the lowest on $A$. craccivora (feeding on 126 aphids), while, that of $A$. variegate (Goeze) was the highest on L. erysimi (feeding 155.4 aphids) and the lowest on B. brassicae (feeding 112 aphids) during their larval stages. Fourth instar individual larval weight of $C$. septumpunctata was recorded the highest (26.82 $\mathrm{mg}$ ) when fed on A. craccivora and the lowest (13.9 mg) when fed on B. brassicae, while the 4 th instar larval weight of $A$. variegate was only $12.82 \mathrm{mg}$ and $11.34 \mathrm{mg}$ when fed on same aphid species. Pupal and adult weight was also recorded the highest for C. septumpunctata as compared to A. variegata. Similar result was obtained for weights of adult when larvae fed on $A$. craccivora. The weight of female was observed relatively higher than that of male from this study for both beetle species. There was a positive correlation between predation and weight gained by larvae with respect to all aphid species. From this study, it can be concluded that $C$. septumpunctata seems better promising species of predators of aphids, especially beneficial in biological control of aphid species.
\end{abstract}

Key words: Aphid species, Biological control, Coccinellid species, Predator

\section{INTRODUCTION}

Insect pests have always been a threat to agriculture productivity in Nepal resulting in lower productivity as compared to advanced agricultural countries of the world. Various chemicals (pesticides) are applied against different insect pests (Pearson, 2004). Due to the intensive and indiscriminate use of many pesticides poison, people suffer from many diseases, and some of these are chronic for human beings. Besides contaminating food and food products, pesticides have been accumulating in the soil, air and water to a critical stage. This calls for a safe and cheap control method. This can only be achieved by the practice of Integrated Pest Management (IPM); a pest control management which ensures environmental safety (Solangi, 2004).

Ladybird beetles are considered important agents in biological control helping to regulate the population of pests in many economically important crops (Obrycki and Kring, 1998).They are predators in both adult and larval phases, presenting an intense search for food and predatory capacity (Vandenberg, 2002; Olkowski et al., 1990; Oliveira et al., 2004). Ladybird beetles or coccinellids 
have significant importance as a biological control agent because of its extend to control many softbody insects pest especially the aphids on which its larvae as well as adult stages feed vigorously.

In the world, aphids are very severe pest of agriculture. Aphid attacks on variety of plants and both nymphs and adults suck the cell sap and reduce the plants vigour and growth.Aphids are responsible of transferring about $60 \%$ of all type of plant viruses in the whole world.They also produce honey dew which results in sooty mold development (Gilkeson and Kelin, 2001). The general objective of the experiment was to select ladybird beetle as effective biocontrol agents of aphids through the lifecycle study of ladybird beetles on four different species of aphids. whereas, the study specifically aimed:

- To study biology of two coccinellid beetle species on four aphid species

- To evaluate the feeding efficiency of two ladybird beetle species on four aphid species

- To select the effective ladybird beetle as bio-agent for the bio-control of four aphid species

\section{MATERIALS AND METHODS}

The experiment was conducted in Mass-rearing Laboratory of Entomology Division, Nepal Agricultural Research Council (NARC), Khumaltar, Lalitpur $\left(27.6644^{\circ} \mathrm{N}\right.$ latitude and, $85.3188^{\circ} \mathrm{E}$ longitude). For the experiment, two coccinellid species; Coccinella septumpunctata Linn. and Adonia variegata (Goeze) each was fed on four different aphids; Aphis craccivora (Koch) ,Brevicoryne brassicae Linn., Lipaphis erysimi (Kaltenbach) and Myzuspersicae (Sulzer). The comparative biology and feeding behavior of beetles was studied for evaluating their efficacy as effective biocontrol agent.

\section{Collection and stock culture of two coccinellid species}

The adults of $C$. septumpunctata and A. variegata was collected from premises of Nepal Agricultural Research Council, Khumaltar, Lalitpur (From field of Agriculture Botany Division and Entomology Division) and reared in Mass-rearing Laboratory of Entomology Division within $27.6644^{\circ} \mathrm{N}$ latitude and, $85.3188^{\circ} \mathrm{E}$ longitude. The beetle pairs of both species was kept in separate ventilated plastic container $(18 \times 12 \times 8 \mathrm{~cm})$ and offered fresh and live aphids available in the field. The observation on egg laying was carried out twice a day (morning and evening). The corrugated papers were provided to each plastic container for influencing egg laying on the paper for easy collection of eggs. The eggs laid by females was collected and subjected for further observations.

For stock culture of aphids, A. craccivora was reared on faba bean, B. brassicae on cabbage, L. erysimi on mustard and raddish and $M$. persicae on tomato plants, respectively.

\section{Laboratory experiment}

The collected egg mass of each species of coccinellid beetle was kept in a separate ventilated plastic container $(6.5 \times 7.5 \mathrm{~cm})$ and observed twice a day (morning and evening) for hatching. After hatching of the eggs, the larva was kept in four different ventilated plastic containers (5 larvae per container) each replicating five times. This experimental set up was same for both species of coccinellid, i.e. feeding two species of coccinellid on four species of aphids, which were replicated five times.

The larva in each plastic container was provided with counted number of aphids each day. Ten aphids were given initially and aphid number was increased by five after every two days. This process continued till all the larvae pupated. Pupae were kept undisturbed for emergence of adult. The adults were then paired and kept in ventilated plastic container $(6.5 \times 7.5 \mathrm{~cm})$ for observation 
of egg laying capacity and longevity of the adults. The weight of each instar larvae and adult within $12 \mathrm{hr}$ of emergence and just after death was recorded.

\section{Data analysis}

The information collected from the laboratory experiment was coded, tabulated and analyzed by using R-Studio and Microsoft Excel in the computer. Both descriptive and analytical methods were used to analyze the data.

\section{RESULTS AND DISCUSSION}

\section{Feeding capacity of two species of ladybird beetle during larval period}

Laboratory study revealed that $C$. septumpunctata consumed relatively higher number of aphids during its larval period compared with $A$. variegata. The higher consumption of aphid by the former is due to its larger size compared with later and more requirements of nutrients for its development. Figure 1 showed that consumption of L. erysimi was relatively higher than other aphid species. The low consumption of $A$. craccivora was recorded which is followed by $B$. brassicae. It is because of the $B$. brassicae covered with powdery material which was not palatable for ladybird beetles which supports previous findings of Jonathan (2005) and presence of wings in A. craccivora which makes larvae difficult to feed on aphids.

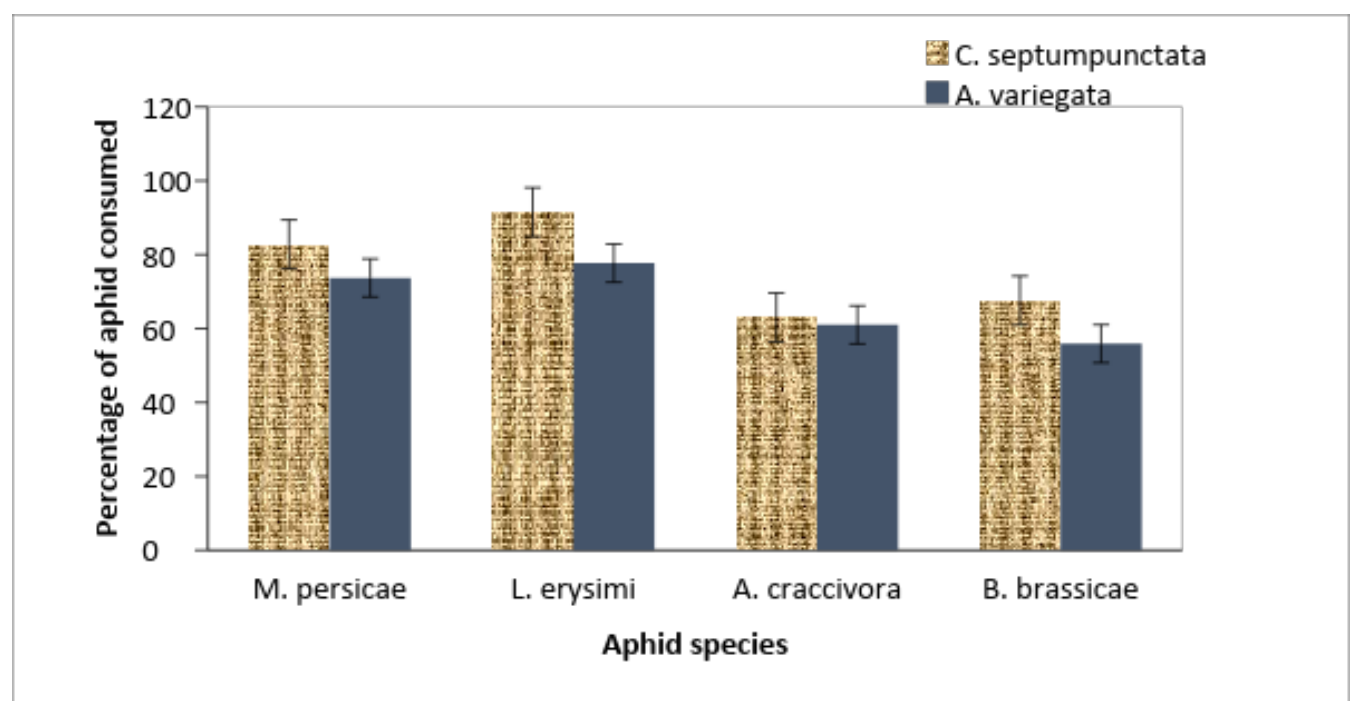

Figure 1: Different aphid species consumed by two beetle species during larval period in laboratory condition of NARC, Khumaltar, 2016

\section{Larval weight of two species of ladybird beetle on consuming four different aphid species}

Laboratory analysis showed almost similar effect of each four aphid species on weight gain by larvae of $C$. septumpunctata in $1^{\text {st }}, 2^{\text {nd }}$ and $3^{\text {rd }}$ instar. There was visible difference in weight gain by $4^{\text {th }}$ instar larvae of C. septumpunctata as shown in Figure 2.

In case of $A$. variegata, similar effects of each four aphid species on weight gain by larvae was observed in $1^{\text {st }}$ and $2^{\text {nd }}$ instar, while there was difference in weight gain by larvae of $A$. variegata in $3^{\text {rd }}$ and $4^{\text {th }}$ instar, which is presented in Figure 5. The results shown by Figures 2 and 3 are very similar to the finding of Ali and Rizwi (2009) which is also explained by study of Ahmad (Ahmad 2015). 


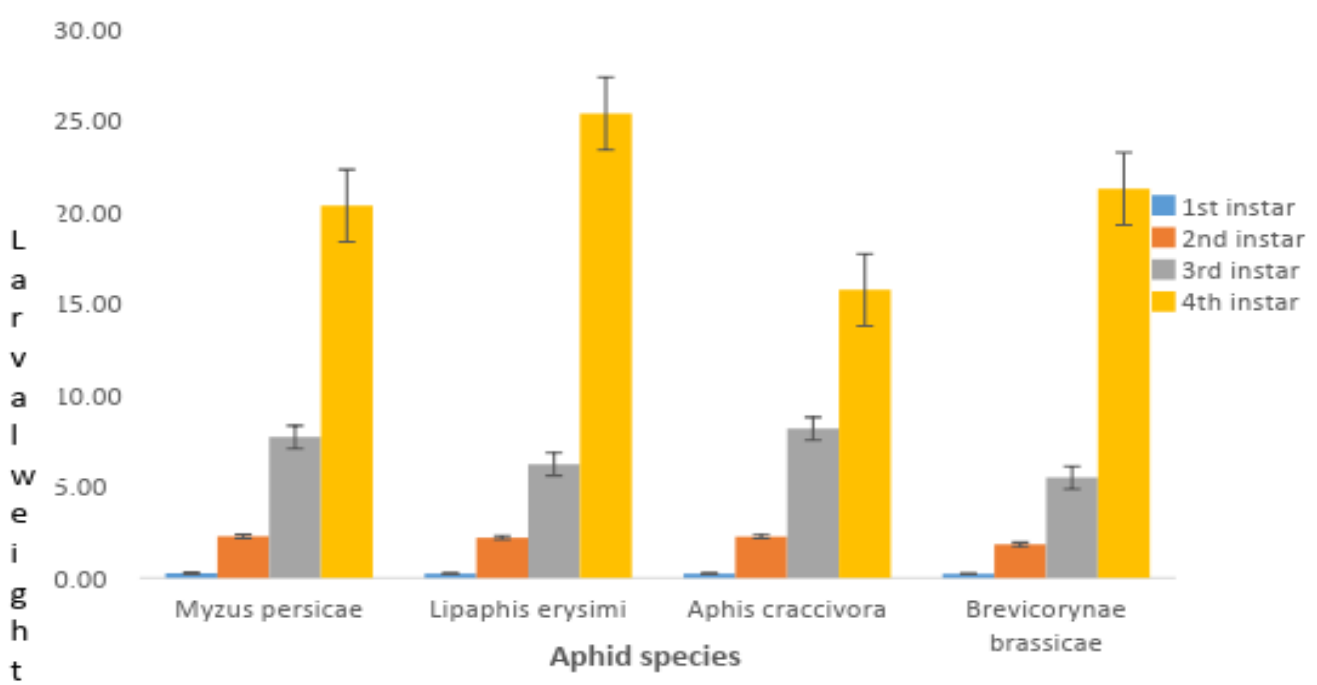

Figure 2: Larval weight (mg) of $C$. septumpunctata fed on four different aphid species in laboratory condition of NARC, Khumaltar, 2016

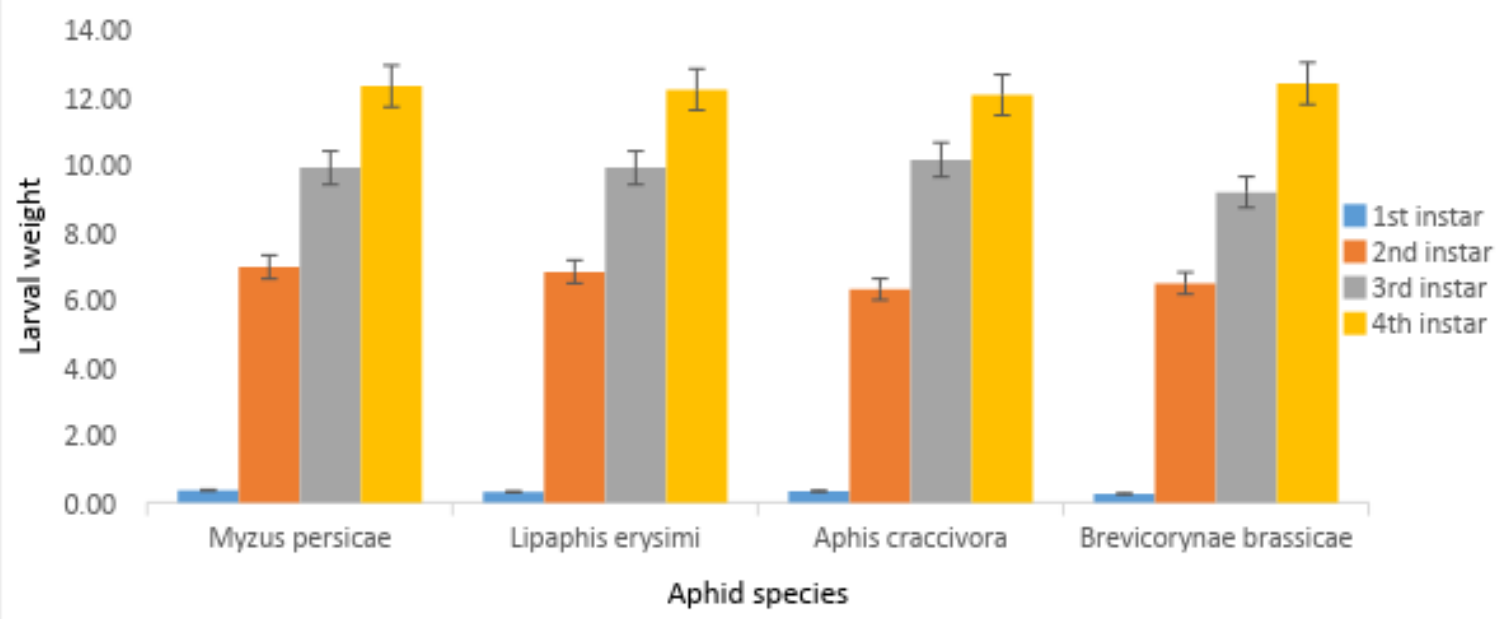

Figure 3: Larval weight (mg) of $A$. variegata fed on four different aphid species in laboratory condition of NARC, Khumaltar, 2016

\section{Pupal weight of two species of ladybird beetle fed on four different aphid species}

Highest pupal weight (26.32 $\mathrm{mg}$ of C. septumpunctata and $12.54 \mathrm{mg}$ of A. variegata) was recorded on $C$. septumpunctata and $A$. variegata fed on $A$. craccivora. It was followed by feeding with M. persicae (22.78 $\mathrm{mg}$ of C. septumpunctata and $11.74 \mathrm{mg}$ of A. variegata), L. erysimi (20.54 $\mathrm{mg}$ of C. septumpunctata and $11.72 \mathrm{mg}$ of $A$. variegata) and B. brassicae (15.92 $\mathrm{mg}$ of C. septumpunctata and $11.34 \mathrm{mg}$ of $A$. variegata) respectively.

Pupal weight observation showed significant difference in weight feeding larvae with different aphid species except for feeding on L. erysimi (Table 1). 
Table 1: Pupal weight (mg) of two species of ladybird beetle fed on four different aphid species in laboratory condition of NARC, Khumaltar, 2016

\begin{tabular}{|c|c|c|c|c|}
\hline Aphid species & $\begin{array}{l}\text { C. septumpunctata } \\
\text { Mean } \pm \text { SE }\end{array}$ & $\begin{array}{l}\text { A. variegata } \\
\text { Mean } \pm \mathrm{SE}\end{array}$ & t- test & \\
\hline M. persicae & $22.78 \pm 1.874$ & $11.74 \pm 0.203$ & 0.011 & $* *$ \\
\hline $\begin{array}{l}\text { L. erysimi } \\
\text { A. craccivora }\end{array}$ & $\begin{array}{l}20.54 \pm 2.349 \\
26.32 \pm 0.372\end{array}$ & $\begin{array}{l}11.72 \pm 0.215 \\
12.54 \pm 0.050\end{array}$ & $\begin{array}{l}0.076 \\
0.000\end{array}$ & $* * *$ \\
\hline B. brassicae & $15.92 \pm 2.073$ & $11.34 \pm 0.136$ & 0.018 & $* *$ \\
\hline $\begin{array}{l}\text { CV } \\
\text { LSD }\end{array}$ & $\begin{array}{c}15.190 \\
4.477\end{array}$ & $\begin{array}{l}2.881 \\
0.470 \\
\end{array}$ & & \\
\hline
\end{tabular}

Adult weight of two species of ladybird beetle on feeding larvae of each species with four different aphid species

The result of feeding of $C$. septumpunctata and A. variegata larvae on four different species of aphids gave significant difference in weight gain by adult (both male and female) of each species of lady beetles as shown in Table 2. The weights of female ladybird beetles were recorded higher as compared to male beetles.

The highest weights of male and female of C. septumpunctata and A. variegata were recorded feeding on A. craccivora \{C. septumpunctata: male (25.54 mg), female (33.58 mg) and A. variegata; male $(11.06 \mathrm{mg})$, female $(13.6 \mathrm{mg})\}$. This weight was followed by feeding with $M$. persicae, $L$. erysimi and $B$. brassicae, respectively for $C$. septumpunctata. In case of $A$. variegata the order was found to be different for male and female. Female $A$. variegata followed the feeding order of $M$. persicae, L. erysimi and B. brassicae after A. variegata while for male A. variegata it was in order of L. erysimi, $M$. persicae and $B$. brassicae respectively.

Many studies have reported $A$. craccivora (Koch) as an essential prey for ladybird beetles, viz. C. septempunctata (Hodek, 1960), P. dissecta (Omkar \& Mishra, 2005).

Table 2: Adult weight (mg) of two species of ladybird beetle fed on four different aphid species in laboratory condition of NARC, Khumaltar, 2016.

\begin{tabular}{llcccc}
\hline \multirow{2}{*}{ Aphid species } & \multicolumn{2}{c}{$\begin{array}{c}\text { C. septumpunctata } \\
\text { Mean } \pm \text { SE }\end{array}$} & $\begin{array}{c}\text { A. variegata } \\
\text { Mean } \pm \text { SE }\end{array}$ & t- test \\
\hline \multirow{2}{*}{ Myzus persicae } & Male & $24.7 \pm 0.4$ & $10.34 \pm 0.305$ & 0.000 & $* * *$ \\
& Female & $31.94 \pm 0.607$ & $13.02 \pm 0.091$ & 0.000 & $* * *$ \\
\multirow{2}{*}{ Lipaphiserysimi } & Male & $23.98 \pm 0.321$ & $10.52 \pm 0.324$ & 0.000 & $* * *$ \\
& Female & $31.54 \pm 0.520$ & $12.92 \pm 0.237$ & 0.000 & $* * *$ \\
Aphis craccivora & Male & $25.54 \pm 0.201$ & $11.06 \pm 0.380$ & 0.000 & $* * *$ \\
\multirow{2}{*}{ Brevicorynae brassicae } & Female & $33.58 \pm 0.813$ & $13.6 \pm 0.176$ & 0.000 & $* * *$ \\
& Male & $22.46 \pm 0.386$ & $9.18 \pm 0.131$ & 0.000 & $* * *$ \\
CV & Female & $29.22 \pm 1.054$ & $12.62 \pm 0.115$ & 0.000 & $* * *$ \\
& Male & 2.985 & 6.378 & & \\
LSD & Female & 5.844 & 2.629 & & \\
& Male & 0.994 & 0.903 & & \\
\hline
\end{tabular}

$S E=$ Standard error. ${ }^{* * *}$ significant at 0.01 level, respectively by $t$-test 
Egg laying capacity of two species of ladybird beetle fed on four different aphid species

According to laboratory study, the highest egg laying (54 eggs per day by C. septumpunctata and 40 eggs per day by $A$. variegata) was recorded feeding on $A$. craccivora which was followed by feeding on $M$. persicae (51 eggs per day by C. septumpunctata and 33 eggs per day by $A$. variegata), $L$. erysimi (47 eggs per day by $C$. septumpunctata and 27 eggs per day by $A$. variegata) and $B$. brassicae (46 eggs per day by C. septumpunctata and 26 eggs per day by A. variegata) as shown in Table 3.

This result is supported by finding of Ngammuang (1987) who reported that the number of eggs deposited per female was $181.07 \pm 66.37$ (highest) on $A$. craccivora.

Table 3: Egg laying capacity of two species of ladybird beetle fed on four different aphids in laboratory condition of NARC, Khumaltar, 2016

\begin{tabular}{lclrl}
\hline Aphid species & $\begin{array}{c}\text { C. septumpunctata } \\
\text { Mean } \pm \text { SE }\end{array}$ & $\begin{array}{l}\text { A. variegata } \\
\text { Mean } \pm \text { SE }\end{array}$ & t-test & \\
\hline M. persicae & $50.548 \pm 3.564$ & $32.769 \pm 2.389$ & 0.004 & $* * *$ \\
L. erysimi & $46.723 \pm 3.673$ & $27.303 \pm 2.201$ & 0.000 & $* * *$ \\
A. craccivora & $53.728 \pm 3.382$ & $40.031 \pm 3.305$ & 0.000 & $* * *$ \\
B. brassicae & $45.881 \pm 3.681$ & $25.740 \pm 2.130$ & 0.000 & $* * *$ \\
\hline
\end{tabular}

*** Significant at 0.01 level by t-test

Head capsule measurement two species of ladybird beetle fed on consuming four different aphid species

Analysis of head capsule measurement revealed that there was significant difference in larval growth in each instar as shown in Table 4. It was clear that while moulting from third instar to fourth instar the highest $\{C$. septumpunctata $(0.944 \mathrm{~mm})$ and $A$. variegata $(0.590 \mathrm{~mm})\}$ headcapsule was measured with the larvae fed on A craccivora for both species of ladybird beetles.

Table 4: Head capsule measurement $(\mathrm{mm})$ of two species of ladybird beetle fed on four different aphid species in laboratory condition of NARC, Khumaltar, 2016

\begin{tabular}{|c|c|c|c|c|c|}
\hline Aphid species & & $\begin{array}{c}\text { C. septumpunctata } \\
\text { Mean } \pm \text { SE }\end{array}$ & $\begin{array}{l}\text { A. variegata } \\
\text { Mean } \pm \text { SE }\end{array}$ & t-test & \\
\hline \multirow{3}{*}{ M.persicae } & $1^{\text {st }}-2^{\text {nd }}$ instar & $0.448 \pm 0.021$ & $0.151 \pm 0.017$ & 0.000 & $* * *$ \\
\hline & $2^{\text {nd }}-3^{\text {rd }}$ instar & $0.662 \pm 0.022$ & $0.264 \pm 0.009$ & 0.000 & $* * *$ \\
\hline & $3^{\text {rd }}-4^{\text {th }}$ instar & $0.834 \pm 0.027$ & $0.421 \pm 0.008$ & 0.000 & $* * *$ \\
\hline \multirow{3}{*}{ L.erysimi } & $1^{\text {st }}-2^{\text {nd }}$ instar & $0.427 \pm 0.025$ & $0.144 \pm 0.012$ & 0.001 & $* * *$ \\
\hline & $2^{\text {nd }}-3^{\text {rd }}$ instar & $0.620 \pm 0.024$ & $0.269 \pm 0.012$ & 0.000 & $* * *$ \\
\hline & $3^{\text {rd }}-4^{\text {th }}$ instar & $0.848 \pm 0.023$ & $0.437 \pm 0.013$ & 0.000 & $* * *$ \\
\hline \multirow{3}{*}{ A. craccivora } & $1^{\text {st }}-2^{\text {nd }}$ instar & $0.414 \pm 0.030$ & $0.151 \pm 0.013$ & 0.003 & $* *$ \\
\hline & $2^{\text {nd }}-3^{\text {rd }}$ instar & $0.662 \pm 0.029$ & $0.311 \pm 0.0008$ & 0.000 & $* * *$ \\
\hline & $3^{\text {rd }}-4^{\text {th }}$ instar & $0.944 \pm 0.027$ & $0.590 \pm 0.003$ & 0.000 & $* * *$ \\
\hline \multirow{3}{*}{ B. brassicae } & $1^{\text {st }}-2^{\text {nd }}$ instar & $0.427 \pm 0.023$ & $0.165 \pm 0.012$ & 0.001 & $* * *$ \\
\hline & $2^{\text {nd }}-3^{\text {rd }}$ instar & $0.607 \pm 0.027$ & $0.255 \pm 0.008$ & 0.000 & $* * *$ \\
\hline & $3^{\text {rd }}-4^{\text {th }}$ instar & $0.779 \pm 0.013$ & $0.362 \pm 0.010$ & 0.000 & $* * *$ \\
\hline \multirow[t]{3}{*}{$\mathrm{CV}$} & $1^{\text {st }}-2^{\text {nd }}$ instar & 9.891 & 23.657 & & \\
\hline & $2^{\text {nd }}-3^{\text {rd }}$ instar & 9.401 & 6.561 & & \\
\hline & $3^{\text {rd }}-4^{\text {th }}$ instar & 4.034 & 4.030 & & \\
\hline \multirow[t]{3}{*}{ LSD } & $1^{\text {st }}-2^{\text {nd }}$ instar & 0.058 & 0.050 & & \\
\hline & $2^{\text {nd }}-3^{\text {rd }}$ instar & 0.082 & 0.024 & & \\
\hline & $3^{\text {rd }}-4^{\text {th }}$ instar & 0.047 & 0.025 & & \\
\hline
\end{tabular}




\section{CONCLUSION}

Comparing the feeding efficiency of two species of beetle, C. septumpunctata was found to consume more number of aphids than A. variegata. This clarified the effectiveness of former as effective bio-control of aphid providing better management of aphid than later one.

Larval, pupal and adult weights of beetle species were recorded highest when fed on $A$. craccivora. Although the consumption rate was observed least for $A$. craccivora and highest for $L$. erysimi, development was found to be better with $A$. craccivora. Therefore on the basis of this study this was also supported by several previous findings, $A$. craccivora seemed to be better choice for laboratory rearing of beetles for mass production.

Fecundity is one of the important aspects for multiplication of predator. It was too found to be highest for female beetle fed on A. craccivora and followed by M. persicae, L. erysimi and recorded least for $B$. brassicae for both beetle species. Eggs laid by two beetle species differ significantly fed on all types of aphid. Therefore C. septumpunctata was superior in terms of fecundity too. Therefore C. septempunctata performs better in progeny development as well as for consumption of prey offering economic significance in biological control of aphid.

Comparing the predation efficacy of different larval stages, this study found $4^{\text {th }}$ instars larvae as voracious feeder. Larvae of ladybird beetle behaved aggressively and making it difficult to provide enough aphids to satisfy their voracious appetites. Therefore it can be concluded that $4^{\text {th }}$ instars larvae are better in terms of management of aphids successfully.

From the results of this experiment, we can conclude that $C$. septumpunctata is superior and effective bio-control agent in comparison with $A$. variegata. The overall development of two species of predator was recorded better when fed on A. craccivora. Thus for mass rearing purpose, predators can be given the same aphid species. M. persicaeand L. erysimican be given on unavailability of $A$. craccivora for quick and satisfactory development as performance of these beetles was satisfactory on feeding with these species.

\section{ACKNOWLEDGEMENT}

The authors are extremely thankful to Entomology Division, Nepal Agricultural Research Council (NARC), Khumaltar, Lalitpur, Nepal for proving laboratory facilities to conduct research. Authors are also grateful to whole staff and daily wage workers of Entomology Division, NARC for their kind support and help.

\section{REFERENCES CITED}

Cotrell, T.E. (2005). Predation and cannibalism of lady beetle eggs by adult lady beetles. Biological Control 34(2): 159-164.

Elhabi, M., Sekkat, A., Eljadd, L., \& Boumezzough, A. (2000). Biology of Hippodamia variegate (Goeze) and its suitability under greenhouse conditions. Journal of Applied Entomology 124 (9/10): 365-374.

Gilkeson, L., \& Kelin, M. (2001). Natural enemies of crop insect pests. Cooperative Extention, Cornell University, Ithea, New York. 63 pp.

Hodek, I., \& Honek, A. (1996). Ecology of Coccinellidae. Kluwer Academic Publishers, London, UK.

Jonathan, G., \& Lundgren, R.N. (2014). Wiedenmann Tritrophic Interactions among Bt (Cry3Bb1) corn, aphid prey, and the predator Coleomegilla maculate (Coleoptera: Coccinellidae). Environmental Entomology Article 34(6):1621-1625. 
Obrycki, J.J., \& Kring, T. J. (1998). Predaceous coccinellidae in biological control. Annual Review of Entomology 43(1):295-321.

Oliveira, N.C., Wilcken, C.F., \& Matos, O.C.A. (2004). Biological predator species the coccinellids (Coleoptera: Coccinellidae) Cinaraatlantica as(Wilson).Journal of Entomological Research 48(4):529-533.

Olkowski, W., Shang, A., \& Thiers, P. (1990). Improved biocontrol techniques with lady beetles. IPM Practioner 12:1-12.

Pearson, S.A. (2004). Post embryonic development surival rate and predation potential of Coccinella septumpunctata Linn. in relation to the mustard aphid (Lipaphiserysimi( Kaltenbach)). Journal of Entomological Research 18: 5-10.

Solangi, S. (2007). Searching ability and feeding potential of larvae of 7-spotted beetle Coccinellaseptempunctata L inn. under laboratory and field conditions. Sarhad Journal of Agriculture 23(3):705-711. 